\title{
On Translating Postcolonial African Writing: French Translation of Chimamanda Adichie's Half of a Yellow Sun
}

Sylvia Ijeoma Madueke

University of Alberta

Like many postcolonial African novels written in English, Half of a Yellow Sun (2006) written by Nigerian writer Chimamanda Ngozi Adichie presents many instances of literary hybridity. This paper focuses on these occurrences of hybridity and examines their translation from English into French. The paper considers various manifestations of hybridity in the novel and compares them with the novel's French translation to illuminate translation strategies while analyzing the implications of key translation choices. This paper emphasizes that the translator made a significant effort to employ ethnocentric strategies to preserve the resonances of the author's culture, especially instances of vernacular language inherent in the original text. The paper also notes seemingly arbitrary choices that exoticize and homogenize the translated text. Despite these instances, this paper concludes that the translation managed to maintain a balance between the source text and the target language. 